\title{
Effects of transdermal flunixin meglumine on experimentally induced lameness in adult dairy cattle
}

\author{
M. D. Kleinhenz, ${ }^{1 *}$ P. J. Gorden, ${ }^{1}$ J. S. Smith, ${ }^{1}$ J. A. Schleining, ${ }^{1}$ K. E. Kleinhenz, ${ }^{2}$ J. R. Juarez, ${ }^{2}$ D. Rea, ${ }^{3}$ \\ and J. F. Coetzee ${ }^{1} \dagger \ddagger$ \\ ${ }^{1}$ Department of Veterinary Diagnostic and Production Animal Medicine, lowa State University, Ames 50011 \\ ${ }^{2}$ Department of Animal Science, lowa State University, Ames 50011 \\ ${ }^{3}$ Castle Veterinary Group, Downpatrick, Northern Ireland BT30 9JF
}

\section{ABSTRACT}

Lameness is a common animal health condition with significant production and welfare implications. The transdermal formulation of flunixin meglumine is the only approved drug for pain control in cattle in the United States. Thirty adult dairy cows were enrolled in a study to determine the effect of transdermal flunixin on cattle with induced lameness. Cows were allocated to 1 of 3 treatment groups, with 10 cows per group: lameness and flunixin $(\mathrm{L}+\mathrm{F})$, lameness and placebo $(\mathrm{L}+\mathrm{P})$, or sham induction and placebo $(\mathrm{S}+\mathrm{P})$. An arthritis-synovitis was induced in the distal interphalangeal joint of the left hind lateral digit, using $20 \mathrm{mg}$ of amphotericin B, $6 \mathrm{~h}$ before the application of treatment. Cows enrolled into the sham induction group had $4 \mathrm{~mL}$ of isotonic saline injected into the joint. Cows were dosed with transdermal flunixin at $3.33 \mathrm{mg} / \mathrm{kg}$ $(1 \mathrm{~mL} / 15 \mathrm{~kg})$, or a placebo at $1 \mathrm{~mL} / 15 \mathrm{~kg}$, every $24 \mathrm{~h}$ for $3 \mathrm{~d}$. The first treatment of flunixin or placebo was considered the start of the study, identified as time 0 $\mathrm{h}$. Data were collected from all cows for $120 \mathrm{~h}$ following the initial treatment application. Outcome measures included plasma cortisol; substance P; visual lameness assessment; mechanical nociception threshold (MNT), presented as difference between left and right feet; infrared thermography (IRT), presented as difference between left and right feet; and gait analysis using a pressure mat. Cortisol concentrations were lower for the $\mathrm{L}+\mathrm{F}$ group starting at $1.5 \mathrm{~h}$ after drug administration. Substance P levels showed no evidence for treatment differences among groups. Differences between the left hind MNT and right hind MNT were detected, with

Received May 21, 2018.

Accepted March 10, 2019.

*Current address: Department of Clinical Science, Kansas State University, Manhattan, KS 66506.

$\dagger$ Current address: Department of Anatomy and Physiology, Kansas State University, Manhattan, KS 66506.

$\ddagger$ Corresponding author: jcoetzee@vet.k-state.edu
$\mathrm{S}+\mathrm{P}$ having the lowest difference at -0.04 kilogramsforce (kgf; $95 \%$ CI: -1.86 to $1.78 \mathrm{kgf}$ ), and L+P having the highest at $-2.96 \mathrm{kgf}(95 \% \mathrm{CI}$ : 1.55 to $4.36 \mathrm{kgf})$. The $\mathrm{L}+\mathrm{F}$ group was intermediate at $-2.08 \mathrm{kgf}(95 \%$ CI: 0.89 to $3.27 \mathrm{kgf})$. Similarly, when the difference between the maximum temperatures of the coronary band were examined via IRT, the $\mathrm{L}+\mathrm{P}$ group had the highest difference at $1.64^{\circ} \mathrm{C}\left(95 \% \mathrm{CI}: 1.02\right.$ to $\left.2.26^{\circ} \mathrm{C}\right)$, with the $\mathrm{L}+\mathrm{F}$ and $\mathrm{S}+\mathrm{P}$ groups measuring $0.57^{\circ} \mathrm{C}$ (95\% CI: 0.06 to $\left.1.08^{\circ} \mathrm{C}\right)$ and $0.53^{\circ} \mathrm{C}(95 \%$ CI: -0.2 to $1.25^{\circ} \mathrm{C}$ ) respectively. We found no evidence for differences among treatment groups when analyzing force, contact pressure, step impulse, or stride length. Based on differences in MNT, IRT, and cortisol, transdermal flunixin is an effective analgesic agent for induced lameness. Multiple doses of transdermal flunixin may be required to be clinically effective, based on MNT and IRT data. Further investigation of transdermal flunixin and its analgesic effects is warranted in naturally occurring lameness.

Key words: dairy cattle, nonsteroidal antiinflammatory drug, pour-on, lameness

\section{INTRODUCTION}

Lameness has a direct effect on the welfare of cows (Whay and Shearer, 2017). This has resulted in lameness being included as a component of third-party animal care audits (Coetzee et al., 2017). The prevalence of lameness on dairy farms in the United States varies from $6.9 \%$ to as high as $54.8 \%$ (von Keyserlingk et al., 2012; Adams et al., 2017). Although lameness is regarded as a painful condition, only $53.1 \%$ of veterinarians administer analgesics to acutely lame dairy cattle, with nonsteroidal anti-inflammatory drugs (NSAID) being the preferred drug for analgesia (Fajt et al., 2011).

Currently, flunixin meglumine is the only NSAID approved for use in cattle in the United States. It has been shown to be effective in treating pain associated with induced and natural lameness (Schulz et al., 2011; 
Wagner et al., 2017). Furthermore, flunixin meglumine, as a transdermal formulation, is the first NSAID approved by the US Food and Drug Administration specifically for the control of pain in cattle (FDA, 2017). This approval is limited to the pain associated with foot rot in beef and nonlactating cattle. Despite FDA approval, the use of this formulation of flunixin would be considered extra-label drug use in a mature dairy cow.

Amphotericin B-induced arthritis and synovitis has been shown to be a reliable method to produce transient lameness in cattle (Kotschwar et al., 2009; Schulz et al., 2011; Coetzee et al., 2014). It has been used in cattle, horses, and swine as a lameness model to evaluate analgesic drugs and lameness detection methods (McIlwraith et al., 1979; Kotschwar et al., 2009; Pairis-Garcia et al., 2014). In cattle, the amphotericin B lameness induction model has been used to test a variety of pharmaceuticals, including meloxicam, meloxicam combined with gabapentin, sodium salicylic acid, and flunixin (Kotschwar et al., 2009; Schulz et al., 2011; Coetzee et al., 2014). Schulz et al. (2011) tested flunixin meglumine at a dose of $2.2 \mathrm{mg} / \mathrm{kg}$ via intravenous injection for the amelioration of lameness. In that study, flunixin was shown to improve lameness based on visual lameness scores and pressure gait analysis. In a similar study in swine, the authors were able to show an improvement of lameness scores in sows treated with flunixin meglumine (Pairis-Garcia et al., 2014).

The objective of the present research was to examine the analgesic efficacy of transdermal flunixin meglumine in adult dairy cows with experimentally induced lameness. Our hypothesis was that multiple treatments of transdermal flunixin would be required to provide sufficient analgesia to lame dairy cows, as evidenced by lower lameness scores, higher mechanical nociception thresholds, and an increase in contact force applied to the lame foot.

\section{MATERIALS AND METHODS}

This project was reviewed and approved by the Institutional Animal Care and Use Committee at Iowa State University (Protocol \#7-16-8314-B).

\section{Study Animals}

Thirty adult Holsteins at 60 to $90 \mathrm{~d}$ in milk and in their second or third lactation were enrolled in a study to determine the effect of transdermal flunixin on animals with induced lameness. Cows were eligible for enrollment if they had no record of lameness in the current lactation and were free of clinical signs of lameness (visual lameness score, VLS $=0$ ). Cows were also visu- ally examined for clinical signs of foot rot and digital dermatitis at the time of lameness induction. Cows were randomly allocated to 1 of 3 treatment groups, using the RAND function in a spreadsheet (Excel, Microsoft Corp., Redmond, WA) based on the cow's identification number: (1) lameness induction + transdermal flunixin $(\mathbf{L}+\mathbf{F})$; (2) lameness induction + placebo $(\mathbf{L}+\mathbf{P})$; or (3) sham lameness induction + placebo $(\mathbf{S}+\mathbf{P})$.

Cows in the $\mathrm{L}+\mathrm{F}$ group were dosed with transdermal flunixin at $3.33 \mathrm{mg} / \mathrm{kg}(1 \mathrm{~mL} / 15 \mathrm{~kg}$; Finadyne Transdermal, MDS Animal Health, Dublin, Ireland) every 24 $\mathrm{h}$ for 3 doses as a topical pour-on, following label directions. Cows in the $\mathrm{L}+\mathrm{P}$ and $\mathrm{S}+\mathrm{P}$ groups were given a placebo at the dose of $1 \mathrm{~mL} / 15 \mathrm{~kg}$. The placebo was composed of propylene glycol and red dye, to mimic the test product. The time of the first dose was considered time 0 for the study, and the dose was administered 6 $\mathrm{h}$ after lameness induction. For the second and third doses (24 and $48 \mathrm{~h}$ ), treatment application occurred after the outcome parameters were obtained.

\section{Animal Housing}

Cows were group-housed in the same pen within the barn, with freestalls for resting (one freestall per cow). Only study cows were housed in the pen. Freestalls were bedded with fresh recycled manure solids, which was standard practice for the dairy farm. Cows were milked by study personnel 3 times per day at 0400, 1200, and $2000 \mathrm{~h}$. Housing met the requirements of the Guide for the Care and Use of Agricultural Animals in Research and Teaching (FASS, 2010). A TMR was provided once a day in the morning, with feed push-ups occurring every $6 \mathrm{~h}$ after feeding. The ration was formulated to meet or exceed the National Research Council requirements for lactating dairy cattle (NRC, 2001). The TMR was provided at a feed bunk with self-locking headlocks, and the number of headlocks exceeded the number of cows in the pen. Cows had access to water at all times, except when away from the pen for milking and outcome parameter collection.

\section{Lameness Induction}

Lameness was induced using methods described by Kotschwar et al. (2009). Briefly, the cow was restrained in a custom chute designed for hoof trimming. Using the hydraulic tilt function of the chute, the cow was placed into left lateral recumbency, and the feet were restrained. The chute was used for lameness induction only, including sham injections. Lameness was induced via chemical synovitis and arthritis by injecting $20 \mathrm{mg}$ $(4 \mathrm{~mL})$ of amphotericin B (X-Gen Pharmaceuticals, Inc., Horseheads, NY) into the left hind lateral distal 
interphalangeal joint. Cows in the $\mathrm{S}+\mathrm{P}$ group had 4 $\mathrm{mL}$ of sterile saline injected into the left hind lateral distal interphalangeal joint. For induction, the skin of the lateral aspect of the lateral claw just proximal to the coronary band was clipped and aseptically prepared using alternating chlorhexidine scrub and $70 \%$ alcohol. The distal interphalangeal joint was identified, and a needle was inserted in the joint for amphotericin B or placebo injection. Correct placement of the needle into the joint was confirmed by observation of anatomical landmarks, obtaining joint fluid before injection, and ease of injection. All lameness inductions were performed by the same veterinarian (JAS), to avoid interoperator variation.

\section{Lameness Scoring}

Lameness scores were measured using 2 methods to document the presence of lameness and to visually score the severity of lameness. First, lameness was assessed a visual score (VLS) using a 0 to 4 scale adapted from Sprecher et al. (1997; Table 1). Second, a visual analog score (VAS) was assessed; adapted from Flower and Weary (2006), for the VAS the degree of lameness was marked along a $10-\mathrm{cm}$ line ranging from not lame $(0 \mathrm{~cm})$ to severely lame $(10 \mathrm{~cm})$. Lameness scores were taken before lameness induction $(-6 \mathrm{~h})$, just before the first application of treatment, and at 8, 16, 24, 48, 72, 96 , and $120 \mathrm{~h}$ after initial drug administration. All lameness scores were assigned by an investigator blinded to treatments, who was trained in both systems before commencing the study. All lameness examinations were performed on dry, even, non-sloped concrete floors free of obstructions and debris. To determine lameness scores, the observer watched each cow walk a minimum of $20 \mathrm{~m}$ in a straight line, turn, and walk $20 \mathrm{~m}$ back to the starting point. Cows were allowed to walk naturally with an investigator at the turnaround point.

\section{Cortisol}

Blood samples for plasma cortisol concentration were collected before lameness induction $(-6 \mathrm{~h})$ and at 0.5 ,
$1,1.5,2,3,4,6,8,16,24,32,40,48,56,64,72,80$, 96 , and $120 \mathrm{~h}$ after the first treatment administration. Cows were restrained in headlocks for blood collection at $0.5 \mathrm{~h}$ to $6 \mathrm{~h}$, but only continually restrained for 0.5 to $3 \mathrm{~h}$. The remaining blood collections occurred in treatment chutes, which consisted of a self-locking headgate and side gates. Cows had their heads restrained by rope halter for sample collection. Baseline samples were collected before lameness induction the morning of the experiment. Briefly, up to $20 \mathrm{~mL}$ of blood was collected at the predetermined time points via a jugular venipuncture using a 20-mL syringe (Monoject, Mansfield, MA) and 16-gauge 3.8-cm needle (Monoject). The blood was immediately transferred to a blood tube containing sodium heparin (BD Vacutainer, Franklin Lakes, NJ). The tubes were inverted 3 times and then placed on ice until transported to the laboratory. Once there, the blood was centrifuged at $3,000 \times g$ for $10 \mathrm{~min}$. The plasma was pipetted from the tube and placed into cryovials. The plasma samples were placed on dry ice and stored at $-80^{\circ} \mathrm{C}$ until analysis.

Cortisol concentrations were determined using a commercially available radioimmunoassay (MP Biomedicals, Santa Ana, CA). Samples were run in duplicate and repeated if large differences in cortisol concentrations among the duplicate samples were determined. The assay had a detection range of 0.64 to $150 \mathrm{ng} /$ $\mathrm{mL}$. The coefficient of variation for the intra-assay variability was $16.7 \%$, and the inter-assay variability was calculated to be $16.0 \%$.

\section{Substance $P$}

Blood samples for substance $\mathrm{P}$ determination were collected before lameness induction $(-6 \mathrm{~h})$ and at 1 , $2,8,24,48,72,96$, and $120 \mathrm{~h}$ after induction. At each collection, $6 \mathrm{~mL}$ of whole blood was obtained from the jugular venipuncture taken for cortisol determination and placed into a 6-mL blood tube (BD Vacutainer) containing EDTA and $200 \mu \mathrm{g}$ of benzamidine. Samples were placed on ice until centrifugation within $1 \mathrm{~h}$. Samples were centrifuged at $3,500 \times g$ for $10 \mathrm{~min}$. Plasma was pipetted off and placed into labeled cryovials. Once

Table 1. Visual lameness score (VLS) ${ }^{1}$

\begin{tabular}{ll}
$\begin{array}{l}\text { Lameness } \\
\text { score }\end{array}$ & Clinical description \\
\hline 0 & Normal-Stands and walks normally, with all feet placed with purpose \\
1 & Mildly lame-Stands with flat back but arches when walks, gait is abnormal \\
2 & Moderately lame-Stands and walks with an arched back and short strides on one or more legs \\
3 & Lame-Arched back standing and walking, with one or more limbs favored but at least partially weight bearing \\
4 & Severely lame-Arched back, refuses to bear weight on one limb, may refuse or have great difficulty moving from lying \\
& position
\end{tabular}

${ }^{1}$ Adapted from Sprecher et al. (1997). Permission granted by Elsevier. 
in cryovials, samples were frozen at a temperature of $-80^{\circ} \mathrm{C}$ until analyzed.

Substance P concentrations were determined using an in-house radioimmunoassay as described by Van Engen et al. (2014). Each sample was run in duplicate and the average reported. The coefficient of variation for the intra-assay variability was $14.4 \%$, and the interassay variability was calculated to be $18 \%$.

\section{Mechanical Nociception Threshold}

The mechanical nociception threshold (MNT) was determined using a handheld algometer (FPX 100, Wagner Instruments, Greenwich, CT) before lameness induction $(-6 \mathrm{~h})$ and at $8,16,24,48,72,96$, and 120 $\mathrm{h}$ after initial treatment administration. Cows were restrained in a treatment chute and allowed to stand for all MNT measurements. The MNT was measured using the lateral digit at the level of the coronary band at a point halfway between midline and the heel bulb, by applying slow, steady pressure until the cow responded. MNT measures were taken on both the left (lame) and right (nonlame) hind feet. The average of 3 readings for each foot at each time point was used for analysis. The difference between left and right hind feet MNT measures (left hind minus right hind) were determined for each time point. These differences were used for statistical analysis. The investigator determining the MNT was blinded to treatment and the reading of the algometer, to prevent testing bias. A second investigator recorded algometer readings, to prevent testing bias.

\section{Infrared Thermography}

Infrared thermographic (IRT) images of the dorsolateral aspect of the rear feet were taken before lameness induction $(-6 \mathrm{~h})$ and at $8,16,24,48,72,96$, and $120 \mathrm{~h}$ following initial treatment administration, using a research-grade infrared camera (FLIR SC 660, FLIR Systems AB, Danderyd, Sweden). Cows were restrained in the chute used for MNT measurement, with full access to the feet. Images were obtained at a $45^{\circ}$ angle, 1 $\mathrm{m}$ from the coronary band. Infrared images were analyzed using research-specific computer software (FLIR ExaminIR, Inc., North Billerica, MA) to determine maximum and minimum temperatures. The results of 3 images at each time point were averaged for analysis, and the difference between the temperatures of the left and right hind feet (left hind minus right hind) were determined for each time point. These differences were used for statistical analysis.

\section{Pressure Mat Analysis}

A commercially available pressure/force measurement system (MatScan, Tekscan, Inc., South Boston, MA) was used to record and analyze gait and biomechanical parameters of the affected foot of each cow. The sensing area of the mat was $244 \mathrm{~cm}$ in length and $45 \mathrm{~cm}$ wide. Data were collected before lameness induction $(-6 \mathrm{~h})$ and at $8,16,24,48,72,96$, and $120 \mathrm{~h}$ after initial treatment administration. The pressure mat was calibrated, using a known mass, daily and before each use of the computer software to ensure accuracy of the measurements at each time point. Video synchronization was used to ensure consistent gait between and within cows at each time point. Cows were allowed to move across the mat at their own pace. Using researchspecific software (HUGEMAT Research 5.83, Tekscan, Inc.), force, contact pressure, and impulse in the affected feet and unaffected feet were assessed using the methods described by Coetzee et al. (2014).

The order of outcome measure sampling for baseline $(-6 \mathrm{~h})$ and 8 to $120 \mathrm{~h}$ was as follows: VLS/VAS determination, IRT imaging of each rear foot, MNT measures of each rear foot, blood draw for cortisol and substance $\mathrm{P}$ determination, and pressure mat analysis.

\section{Statistical Analysis}

Contact force was used to determine the number of cows needed per treatment group, as previously described (Kotschwar et al., 2009; Schulz et al., 2011; Coetzee et al., 2014). The study was designed to have a power of 0.80 assuming a difference in effect size $(\Delta)$ of 122 kilograms-force (kgf; $1 \mathrm{kgf}=9.8 \mathrm{~N})$, a standard error $(\sigma)$ of 36.8 , and a statistical inference level $(\alpha)$ of 0.05 . Based on this calculation, a sample size of 10 animals per treatment group was determined.

Concentrations of plasma cortisol and substance $\mathrm{P}$ were log-transformed for normality before statistical analysis. Responses were analyzed using mixed linear models with the cow as the experimental unit, using AR-1 as the covariance structure. Cows nested in a treatment group were designated as a random effect, with treatment, time, treatment by time interaction, and VLS at initial treatment designated as fixed effects. Responses measured include plasma cortisol, substance P, MNT differences, IRT data, VAS, and gait analysis. Pairwise comparisons were performed using the Tukey honestly significant difference (HSD) test. Visual lameness scores were treated as categorical data, and Fisher's exact test was used to compare scores. All statistics were performed using statistical software (JMP Pro 13.0, SAS Institute, Inc., Cary, NC). Statis- 
tical significance was set a priori at $P \leq 0.05$. Data are presented as least squares means.

\section{RESULTS}

\section{Lameness Scoring}

The $\mathrm{L}+\mathrm{F}$ and $\mathrm{L}+\mathrm{P}$ groups had a higher proportion of observations of lameness ( $37 \%$ and $44 \%$ respectively) with a VLS $\geq 1$ than did the $\mathrm{S}+\mathrm{P}$ group $(8 \% ; P<$ 0.0001 ) over the entire study period. At the time of the first flunixin treatment (time 0), all cows in the $\mathrm{L}+\mathrm{F}$ group had a VLS $\geq 2$. In contrast, $80 \%$ of the $\mathrm{L}+\mathrm{P}$ and $10 \%$ of the $\mathrm{S}+\mathrm{P}$ groups had VLS $\geq 1$ at the time of initial treatment (time $0 ; P=0.007$ ). At $16 \mathrm{~h}$ after initial treatment, there was a higher proportion of lameness (VLS $>1$ ) in the $\mathrm{L}+\mathrm{F}$ and $\mathrm{L}+\mathrm{P}$ groups compared with the $\mathrm{S}+\mathrm{P}$ group $(70,60$, and $10 \%$ respectively; $P=0.04)$. At $48 \mathrm{~h}$ after initial treatment and before the final treatment, $70 \%$ of the $\mathrm{L}+\mathrm{F}$ cows were nonlame (VLS $=0$ ), compared with $40 \%$ in the $\mathrm{L}+\mathrm{P}$ and $90 \%$ in $\mathrm{S}+\mathrm{P}$ group $(P=0.08)$. At $72 \mathrm{~h}$ after initial treatment, all of the $\mathrm{L}+\mathrm{F}$ cows were nonlame (VLS $=$ 0 ), compared with $60 \%$ in the $\mathrm{L}+\mathrm{P}$ and $100 \%$ of the $\mathrm{S}+\mathrm{P}$ group $(P=0.09)$.

At the initial treatment following lameness induction, the $\mathrm{L}+\mathrm{F}$ group had higher mean VAS measures (6.7 cm; 95\% CI: 6.1 to $7.3 \mathrm{~cm}$ ) compared with the $\mathrm{L}+\mathrm{P}$ $(2.4 \mathrm{~cm} ; 95 \%$ CI: 1.9 to $3.0 \mathrm{~cm})$ and $\mathrm{S}+\mathrm{P}(0.2 \mathrm{~cm} ; 95 \%$ CI: -0.4 to $0.8 \mathrm{~cm})$ groups $(P<0.0001$; Figure 1$)$. At $8 \mathrm{~h}$ after initial treatment, the mean VAS decreased for the $\mathrm{L}+\mathrm{F}$ and $\mathrm{L}+\mathrm{P}$ groups to $2.1 \mathrm{~cm}(95 \% \mathrm{CI}: 1.6$ to 2.7 $\mathrm{cm})$ and $1.9 \mathrm{~cm}(95 \%$ CI: 1.4 to $2.4 \mathrm{~cm})$ respectively, whereas that of the $\mathrm{S}+\mathrm{P}$ group increased to $0.6 \mathrm{~cm}$ (95\% CI: 0.1 to $1.1 \mathrm{~cm} ; P<0.001$ ).

\section{Cortisol}

There was no evidence of treatment differences before lameness induction $(\mathrm{L}+\mathrm{F} 8.16 \mathrm{ng} / \mathrm{mL}, 95 \%$ CI: 1.87 to $14.44 \mathrm{ng} / \mathrm{mL}$; $\mathrm{L}+\mathrm{P} 14.52 \mathrm{ng} / \mathrm{mL}, 95 \%$ CI: 7.80 to $21.24 \mathrm{ng} / \mathrm{mL} ; \mathrm{S}+\mathrm{P} 18.28 \mathrm{ng} / \mathrm{mL}, 95 \%$ CI: 10.60 to $25.96 \mathrm{ng} / \mathrm{mL} ; P=0.13)$. Starting at $1.5 \mathrm{~h}$ after the initial treatment application, the $\mathrm{L}+\mathrm{F}$ group maintained lower cortisol concentrations than the $\mathrm{L}+\mathrm{P}$ and $\mathrm{S}+\mathrm{P}$ groups (Figure 2). At $8 \mathrm{~h}$, mean cortisol levels were $4.45 \mathrm{ng} / \mathrm{mL}(95 \%$ CI: -1.84 to $10.73 \mathrm{ng} / \mathrm{mL}$ ) in the $\mathrm{L}+\mathrm{F}$ group, compared with $16.35 \mathrm{ng} / \mathrm{mL}$ (95\% CI: 9.63 to $23.07 \mathrm{ng} / \mathrm{mL}$ ) and $17.82 \mathrm{ng} / \mathrm{mL}(95 \%$ CI: 10.13 to $25.50 \mathrm{ng} / \mathrm{mL}$ ) in the $\mathrm{L}+\mathrm{P}$ and $\mathrm{S}+\mathrm{P}$ groups respectively $(P<0.0001)$. The $\mathrm{L}+\mathrm{F}$ group had lower cortisol levels at $16 \mathrm{~h}$ compared with the $\mathrm{L}+\mathrm{P}$ and $\mathrm{S}+\mathrm{P}$ groups $(4.07$ $\mathrm{ng} / \mathrm{mL}, 95 \%$ CI: -2.22 to $10.35 \mathrm{ng} / \mathrm{mL} ; 18.84 \mathrm{ng} / \mathrm{mL}$,
95\% CI: 12.12 to $25.56 \mathrm{ng} / \mathrm{mL} ; 26.42 \mathrm{ng} / \mathrm{mL}, 95 \%$ CI: 18.74 to 34.10 , respectively; $P=0.007$ ). Additionally, cortisol levels in the $\mathrm{L}+\mathrm{F}$ cows were lower than those among the $\mathrm{L}+\mathrm{P}$ cows at $24 \mathrm{~h}(4.12 \mathrm{ng} / \mathrm{mL}, 95 \%$ CI: -2.17 to $10.41 \mathrm{ng} / \mathrm{mL}$, vs. $17.58 \mathrm{ng} / \mathrm{mL}, 95 \%$ CI: 10.87 to $24.30 \mathrm{ng} / \mathrm{mL} ; P=0.0052$ ).

\section{Substance $P$}

We found no evidence of treatment differences with regard to substance $\mathrm{P}$ concentration levels (Table 2). The $\mathrm{L}+\mathrm{P}$ group had mean substance $\mathrm{P}$ concentrations (84.59 pg/mL; 95\% CI: 73.12 to $96.05 \mathrm{pg} / \mathrm{mL}$ ) similar to those of the $\mathrm{L}+\mathrm{F}(81.89 \mathrm{pg} / \mathrm{mL} ; 95 \%$ CI: 72.16 to $91.62 \mathrm{pg} / \mathrm{mL})$ and $\mathrm{S}+\mathrm{P}$ groups $(70.59 \mathrm{pg} / \mathrm{mL} ; 95 \% \mathrm{CI}$ : 55.72 to $85.46 \mathrm{pg} / \mathrm{mL} ; P=0.15)$.

\section{Mechanical Nociception Threshold}

For the left hind foot, we found evidence of treatment differences between groups. The overall MNT means for the left hind foot were $8.46 \mathrm{kgf}$ (95\% CI: 6.93 to $9.99 \mathrm{kgf}$ ), 7.98 (95\% CI: 6.17 to $9.79 \mathrm{kgf}$ ), and 12.34 $\operatorname{kgf}(95 \%$ CI: 10.00 to $14.69 \mathrm{kgf})$ for the $\mathrm{L}+\mathrm{F}, \mathrm{L}+\mathrm{P}$, and

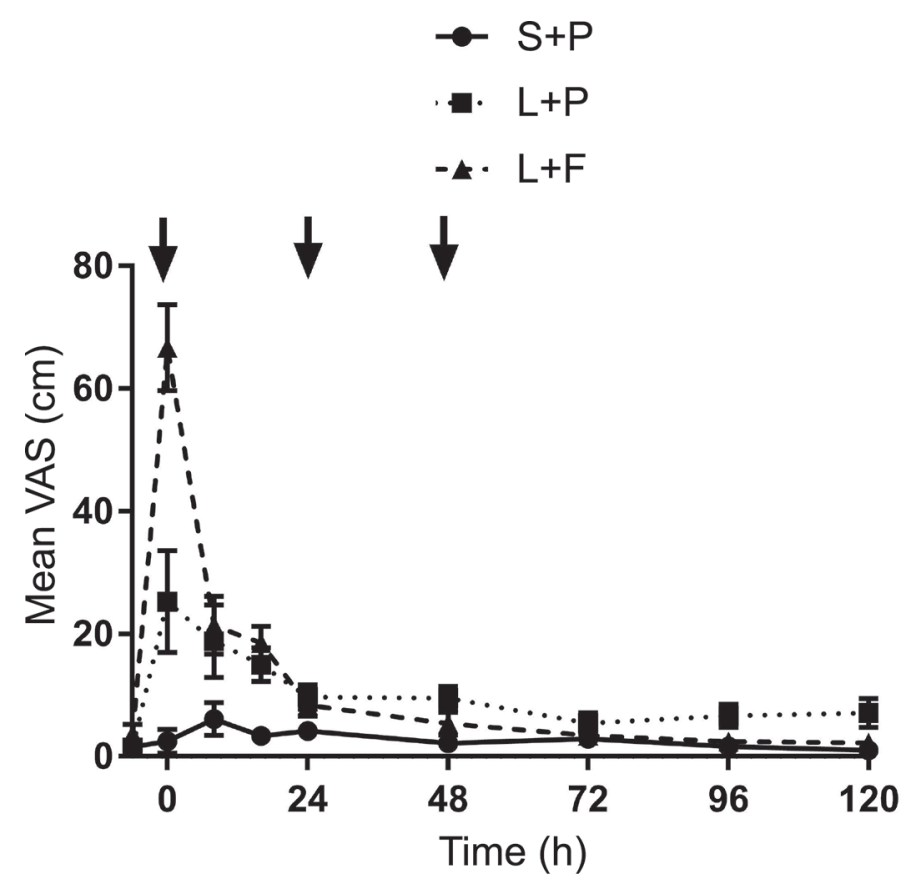

Figure 1. Mean visual analog scores (VAS) for lameness, adapted from Flower and Weary (2006). In the present study, lameness was induced in cows using amphotericin B and treated with transdermal flunixin $(\mathrm{L}+\mathrm{F}, \mathrm{n}=10 ; \downarrow$ indicates dosing times) at $3.33 \mathrm{mg} / \mathrm{kg}(1 \mathrm{~mL} / 15$ $\mathrm{kg})$ or treated with a topical placebo $(\mathrm{L}+\mathrm{P}, \mathrm{n}=10)$ at $1 \mathrm{~mL} / 15 \mathrm{~kg}$. Sham lameness was also induced and treated with a topical placebo $(\mathrm{S}+\mathrm{P}, \mathrm{n}=10)$ at $1 \mathrm{~mL} / 15 \mathrm{~kg}$. Error bars indicate SEM. 

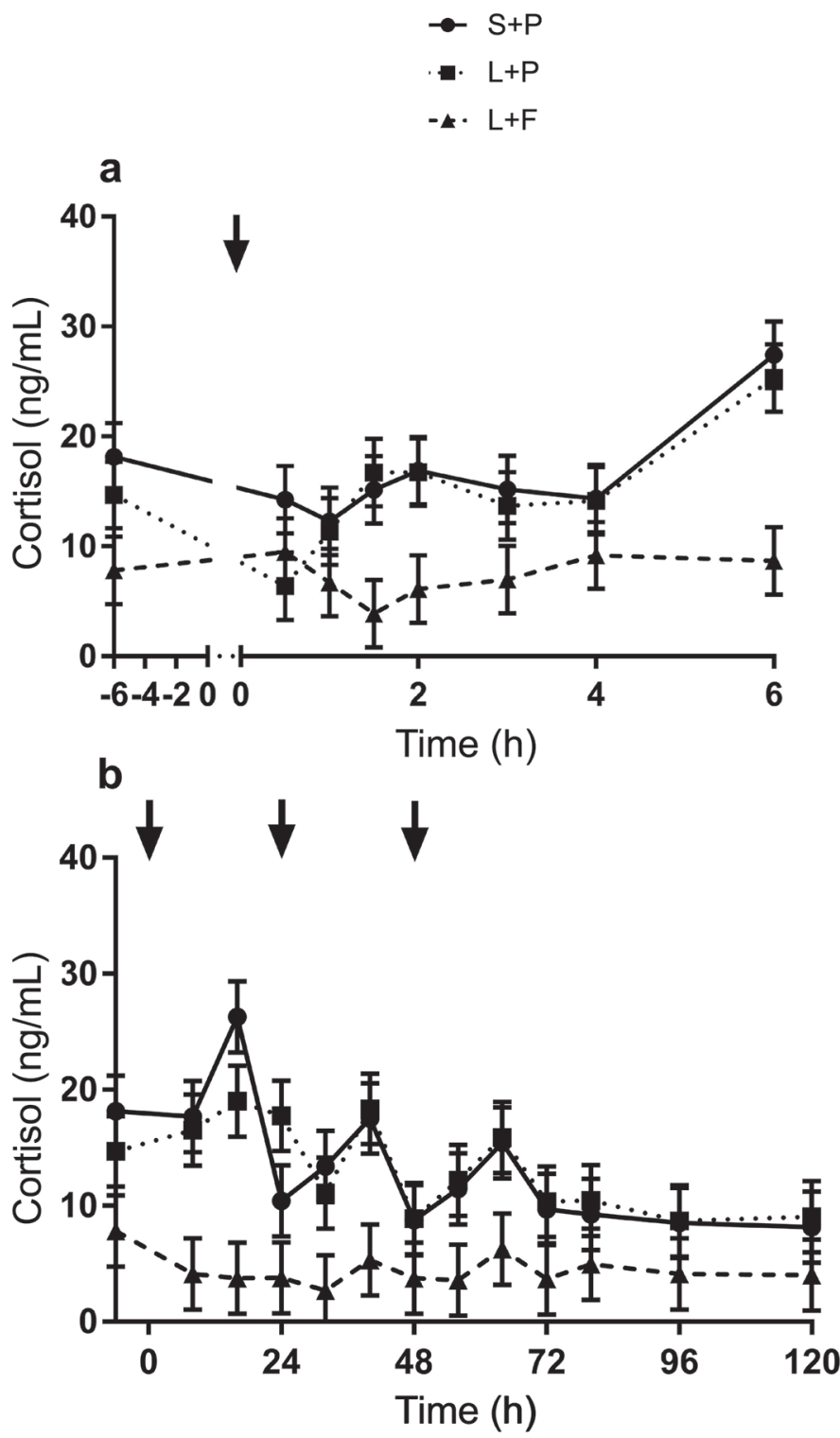

Figure 2. Mean cortisol concentrations (ng/mL) of cows with lameness induced using amphotericin $\mathrm{B}$ and treated with transdermal flunixin ( $\mathrm{L}+\mathrm{F}, \mathrm{n}=10 ; \downarrow$ indicates dosing times) at $3.33 \mathrm{mg} /$ $\mathrm{kg}(1 \mathrm{~mL} / 15 \mathrm{~kg})$, with induced lameness treated with a topical placebo $(\mathrm{L}+\mathrm{P}, \mathrm{n}=10)$ at $1 \mathrm{~mL} / 15 \mathrm{~kg}$, or with sham lameness induction treated with a topical placebo $(\mathrm{S}+\mathrm{P}, \mathrm{n}=10)$ at $1 \mathrm{~mL} / 15 \mathrm{~kg}$. Testing times shown at $-6 \mathrm{~h}$ to $6 \mathrm{~h}$ (a, top) and $-6 \mathrm{~h}$ to $120 \mathrm{~h}$ (b, bottom). Error bars indicate SEM.

$\mathrm{S}+\mathrm{P}$ groups, respectively $(P=0.0026)$. We did observe a time effect in MNT measures, with the $\mathrm{L}+\mathrm{F}(6.29$ kgf; $95 \%$ CI: 4.40 to $8.19 \mathrm{kgf})$ and $\mathrm{L}+\mathrm{P}$ groups ( 8.52 kgf; $95 \%$ CI: 6.43 to $10.63 \mathrm{kgf}$ ) decreasing at $8 \mathrm{~h}$ after initial treatment. At $48 \mathrm{~h}$ following initial treatment the $\mathrm{L}+\mathrm{F}$ MNT measure in the left hind increased to $9.31 \mathrm{kgf}$ (95\% CI: 7.41 to $11.20 \mathrm{kgf}$ ), whereas the $\mathrm{L}+\mathrm{P}$ group MNT measure was $6.57 \mathrm{kgf}$ (95\% CI: 4.45 to 8.69 $\mathrm{kgf})$ and the $\mathrm{S}+\mathrm{P}$ group measure was $13.41 \mathrm{kgf}(95 \%$ CI: 10.83 to $16.00 \mathrm{kgf} ; P<0.0001)$.

We discovered no evidence of treatment differences in the right hind MNT measures. The overall mean MNT for the right hind was $10.54 \mathrm{kgf}$ (95\% CI: 9.33 to 11.75 $\mathrm{kgf}), 10.93 \mathrm{kgf}$ (95\% CI: 9.51 to $12.37 \mathrm{kgf})$, and 12.30 $\mathrm{kgf}(95 \%$ CI: 10.45 to $14.16 \mathrm{kgf})$ for the $\mathrm{L}+\mathrm{F}, \mathrm{L}+\mathrm{P}$, and $\mathrm{S}+\mathrm{P}$ groups respectively $(P=0.23)$.

When the differences between the left hind (lame) and right hind (control) feet were compared, the $\mathrm{L}+\mathrm{P}$ group had a larger mean difference in MNT, $-2.96 \mathrm{kgf}$ (95\% CI: -4.36 to $-1.55 \mathrm{kgf})$ after initial treatment, compared with the $\mathrm{L}+\mathrm{F}(-2.08 ; 95 \% \mathrm{CI}:-3.27$ to 0.89 $\mathrm{kgf})$ and $\mathrm{S}+\mathrm{P}$ (0.04 kgf; 95\% CI: -1.78 to $1.86 \mathrm{kgf})$ groups $(P=0.007)$. Specifically, we found evidence of treatment differences, with $\mathrm{L}+\mathrm{P}$ group having larger MNT differences at 48 and $72 \mathrm{~h}$ compared with the $\mathrm{S}+\mathrm{P}$ group (Figure 2) The mean MNT difference for $\mathrm{L}+\mathrm{P}$ at $48 \mathrm{~h}$ was $-4.53 \mathrm{kgf}(95 \% \mathrm{CI}:-2.53$ to -6.53 $\mathrm{kgf})$, compared with $0.77 \mathrm{kgf}(95 \% \mathrm{CI}$ : -1.52 to 3.08 $\mathrm{kgf})$ in the $\mathrm{S}+\mathrm{P}$ group $(P=0.025)$.

\section{Infrared Thermography}

Evidence of treatment effects $(P=0.001)$ was observed between mean differences of the left- and right-foot maximum temperatures from IRT (Table 2; Figure 3a). The $\mathrm{L}+\mathrm{P}$ group had higher temperature differences $\left(1.64^{\circ} \mathrm{C} ; 95 \%\right.$ CI: 1.01 to $\left.2.26^{\circ} \mathrm{C}\right)$ throughout the entire 120-h study period compared with the $\mathrm{L}+\mathrm{F}$ $\left(0.57^{\circ} \mathrm{C} ; 95 \% \mathrm{CI}: 0.06\right.$ to $\left.1.08^{\circ} \mathrm{C}\right)$ and $\mathrm{S}+\mathrm{P}\left(0.52^{\circ} \mathrm{C} ; 95 \%\right.$ $\mathrm{CI}:-0.20$ to $1.25^{\circ} \mathrm{C}$ ) groups, with the exception of the baseline time point. Differences of the baseline time point were $-0.12^{\circ} \mathrm{C}\left(95 \% \mathrm{CI}:-0.71\right.$ to $\left.0.47^{\circ} \mathrm{C}\right)$ for $\mathrm{L}+\mathrm{F}$; $0.96^{\circ} \mathrm{C}\left(95 \% \mathrm{CI}: 0.27\right.$ to $\left.1.65^{\circ} \mathrm{C}\right)$ for $\mathrm{L}+\mathrm{P}$; and $0.40^{\circ} \mathrm{C}$ $\left(95 \%\right.$ CI: -0.38 to $\left.1.18^{\circ} \mathrm{C}\right)$ for $\mathrm{S}+\mathrm{P}(P=0.12)$.

There was no evidence of treatment differences $(P$ $=0.59$ ) in the mean minimum temperature differences observed (Table 2; Figure 3b). We did observe a treatment by time interaction. The $\mathrm{L}+\mathrm{F}$ group $\left(1.62^{\circ} \mathrm{C}\right.$, 95\% CI: 0.38 to $2.86^{\circ} \mathrm{C}$ ) had higher mean minimum temperature differences at $8 \mathrm{~h}$ compared with the $\mathrm{S}+\mathrm{P}$ group $\left(-0.21^{\circ} \mathrm{C}, 95 \% \mathrm{CI}:-1.73\right.$ to $\left.1.31^{\circ} \mathrm{C} ; P=0.01\right)$. The $\mathrm{S}+\mathrm{P}$ group $\left(0.54^{\circ} \mathrm{C}, 95 \% \mathrm{CI}:-0.98\right.$ to $\left.2.06^{\circ} \mathrm{C}\right)$ had lower mean minimum temperature differences at 24 h compared with the $\mathrm{L}+\mathrm{F}\left(1.89^{\circ} \mathrm{C}, 95 \% \mathrm{CI}\right.$ : 0.66 to $\left.3.12^{\circ} \mathrm{C} ; P=0.006\right)$ and $\mathrm{L}+\mathrm{P}\left(1.83^{\circ} \mathrm{C}, 95 \% \mathrm{CI}: 0.41\right.$ to $\left.3.25^{\circ} \mathrm{C} ; P=0.04\right)$ groups. At $96 \mathrm{~h}$, the $\mathrm{L}+\mathrm{P}$ group $\left(2.51^{\circ} \mathrm{C}, 95 \% \mathrm{CI}: 1.10\right.$ to $\left.3.91^{\circ} \mathrm{C}\right)$ had higher mean minimum temperature differences compared with the $\mathrm{L}+\mathrm{F}$ $\left(-0.03^{\circ} \mathrm{C}, 95 \% \mathrm{CI}:-1.27\right.$ to $\left.1.21^{\circ} \mathrm{C} ; P=0.01\right)$ and $\mathrm{S}+\mathrm{P}$ $\left(0.49^{\circ} \mathrm{C}, 95 \% \mathrm{CI}:-1.04\right.$ to $\left.2.01^{\circ} \mathrm{C} ; P=0.02\right)$ groups. 


\section{Pressure Mat Analysis}

Data for the pressure mat gait analysis is summarized in Table 3.

We observed no differences in mean stride lengths between treatment groups $(P=0.81)$. Mean stride lengths for the $\mathrm{L}+\mathrm{F}, \mathrm{L}+\mathrm{P}$, and $\mathrm{S}+\mathrm{P}$ groups were 77.4 cm (95\% CI: 74.0 to $80.7 \mathrm{~cm}), 79.5 \mathrm{~cm}$ (95\% CI: 75.6 to $83.4 \mathrm{~cm}$ ), and $78.0 \mathrm{~cm}$ (95\% CI: 72.9 to $83.1 \mathrm{~cm})$, respectively.

We discovered no evidence for a difference in the amount of force on the left hind limb between the $\mathrm{L}+\mathrm{F}$ cows (182.2 kgf, 95\% CI: 153.2 to $211.1 \mathrm{kgf}$ ) compared with the L+P (174.7 kgf, 95\% CI: 140.6 to $208.8 \mathrm{kgf}$ ) and $\mathrm{S}+\mathrm{P}$ groups (171.4 kgf, 95\% CI: 127.2 to $215.6 \mathrm{kgf}$; $P=0.91)$. There was evidence of a time effect for all groups, with maximum force of the LH foot being 194.5 kgf (95\% CI: 167.3 to $221.7 \mathrm{kgf})$ at $96 \mathrm{~h}$ and minimum LH force of $161.2 \mathrm{kgf}$ (95\% CI: 133.9 to $188.3 \mathrm{kgf}$ ) at $72 \mathrm{~h}(P=0.03)$. Examination of the nonlame feet revealed no evidence of treatment effects. We did observe evidence of a time effect in the nonlame feet, with the mean force of all groups peaking at $24 \mathrm{~h}$ and $142.9 \mathrm{kgf}$ (95\% CI: 125.8 to $160.1 \mathrm{kgf}$ ), and with a trough at $72 \mathrm{~h}$ and $116.8 \mathrm{kgf}(95 \% \mathrm{CI}: 99.6$ to $134.0 \mathrm{kgf} ; P=0.04)$.

Cows in the $\mathrm{S}+\mathrm{P}$ group had a mean impulse of 136.3 $\mathrm{kg} \cdot \mathrm{s}(95 \%$ CI: 94.0 to $178.6 \mathrm{~kg} \cdot \mathrm{s})$ compared with the $\mathrm{L}+\mathrm{F}$ and $\mathrm{L}+\mathrm{P}$ cows $(125.9 \mathrm{~kg} \cdot \mathrm{s}, 95 \%$ CI: 98.1 to 153.6 $\mathrm{kg} \cdot \mathrm{s} ; 113.8 \mathrm{~kg} \cdot \mathrm{s}, 95 \%$ CI: 81.2 to $146.4 \mathrm{~kg} \cdot \mathrm{s}$, respectively, for the left hind limb; $P=0.51$ ). When evaluating the nonlame limbs, no evidence for treatment effects was observed $(P=0.46)$. Cows in the $\mathrm{L}+\mathrm{F}$ group had higher impulse of $139.8 \mathrm{~kg} \cdot \mathrm{s}$ (95\% CI: 122.0 to 157.5 $\mathrm{kg} \cdot \mathrm{s}$ ) versus $124.1 \mathrm{~kg} \cdot \mathrm{s}(95 \%$ CI: 103.2 to $145.0 \mathrm{~kg} \cdot \mathrm{s})$ and $124.5 \mathrm{~kg} \cdot \mathrm{s}(95 \% \mathrm{CI}: 97.4$ to $151.6 \mathrm{~kg} \cdot \mathrm{s})$ for the $\mathrm{L}+\mathrm{P}$ and $\mathrm{S}+\mathrm{P}$ groups respectively. We found evidence of a time effect in the nonlame limb impulse, with a peak impulse of $191.2 \mathrm{~kg} \cdot \mathrm{s}(95 \%$ CI: 167.1 to $215.3 \mathrm{~kg} \cdot \mathrm{s})$ at $24 \mathrm{~h}$ and a low of $173.1 \mathrm{~kg} \cdot \mathrm{s}$ (95\% CI: 149.1 to 197.2 $\mathrm{kg} \cdot \mathrm{s})$ at $72 \mathrm{~h}(P=0.02)$.

Contact pressure was similar for all treatment groups for the left hind limbs $(P=0.85)$ and nonlame limbs $(P=0.87$; Table 3$)$. We observed a significant time effect $(P<0.0001)$, as contact pressures for all groups decreased over time. Baseline contact pressure was 3.30 $\mathrm{kg} / \mathrm{cm}^{2}$ (95\% CI: 2.88 to $3.71 \mathrm{~kg} / \mathrm{cm}^{2}$ ), with a trough at $72 \mathrm{~h}\left(2.88 \mathrm{~kg} / \mathrm{cm}^{2} ; 95 \%\right.$ CI: 2.46 to $\left.3.29 \mathrm{~kg} / \mathrm{cm}^{2}\right)$ after initial drug administration in all limbs. At $96 \mathrm{~h}$ following initial drug administration, contact pressures for the left hind feet of all groups peaked at $3.55 \mathrm{~kg} /$ $\mathrm{cm}^{2}$ (95\% CI: 3.14 to $\left.3.97 \mathrm{~kg} / \mathrm{cm}^{2}\right)$.

\section{DISCUSSION}

The model used to induce lameness in this study has been previously validated using 4- to 6-mo-old cattle and has been shown to provide a predictable time frame with respect to the onset of lameness (Kotschwar et al., 2009; Schulz et al., 2011; Coetzee et al., 2014). In the present study, amphotericin B was successful in creating lameness, but the degree of lameness in the $\mathrm{L}+\mathrm{P}$

Table 2. Least squares means $( \pm \mathrm{SE})$ of outcome measures in cows with induced lameness

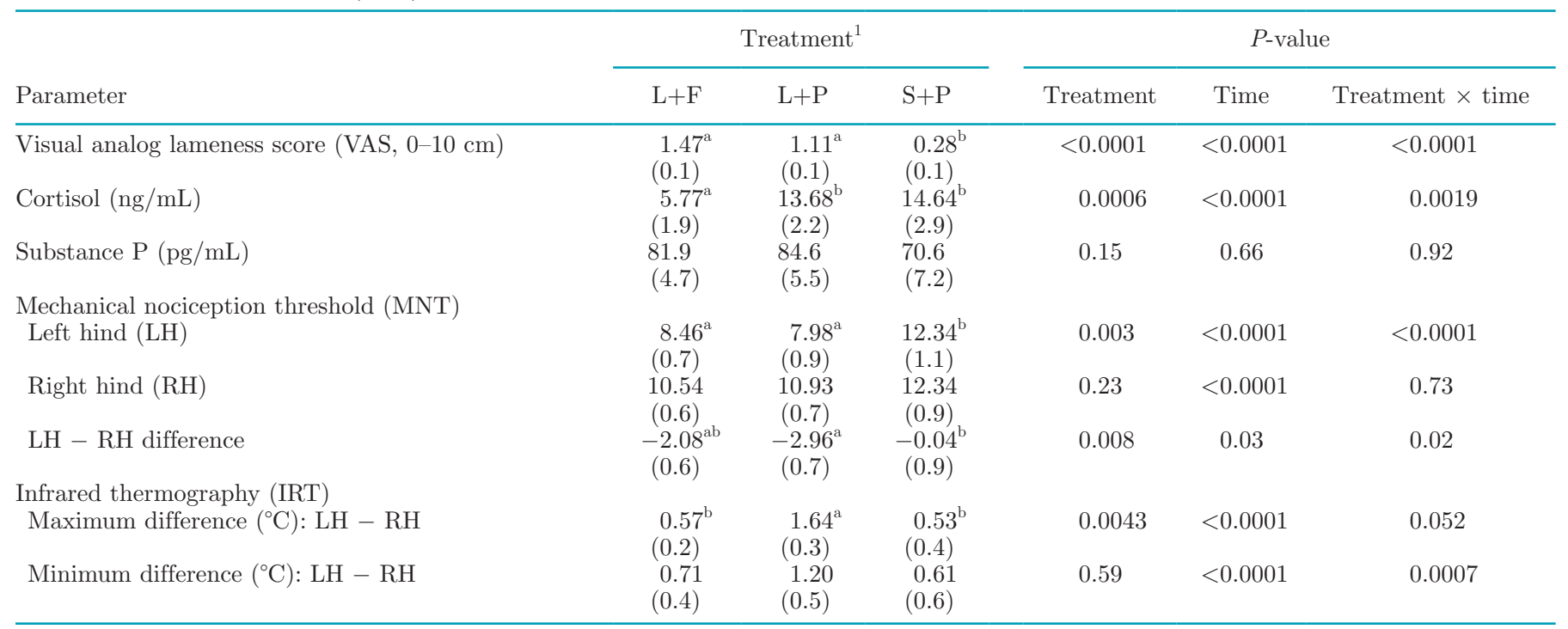

\footnotetext{
${ }^{\mathrm{a}, \mathrm{b}}$ Different superscripts indicate significant differences between treatment groups $(P \leq 0.05)$.
}

${ }^{1}$ Lameness was induced in the left hind lateral distal interphalangeal joint using amphotericin B and treated with transdermal flunixin $(\mathrm{L}+\mathrm{F}$; $\mathrm{n}=10)$ at $3.33 \mathrm{mg} / \mathrm{kg}(1 \mathrm{~mL} / 15 \mathrm{~kg})$ or a topical placebo $(\mathrm{L}+\mathrm{P} ; \mathrm{n}=10)$ at $1 \mathrm{~mL} / 15 \mathrm{~kg}$; or sham lameness was induced $(\mathrm{S}+\mathrm{P} ; \mathrm{n}=10)$ and treated with a topical placebo at $1 \mathrm{~mL} / 15 \mathrm{~kg}$. 
cows was not as severe as that in $\mathrm{L}+\mathrm{F}$, as shown by the VAS measures. The changes in mechanical nociception thresholds and elevations of infrared thermography
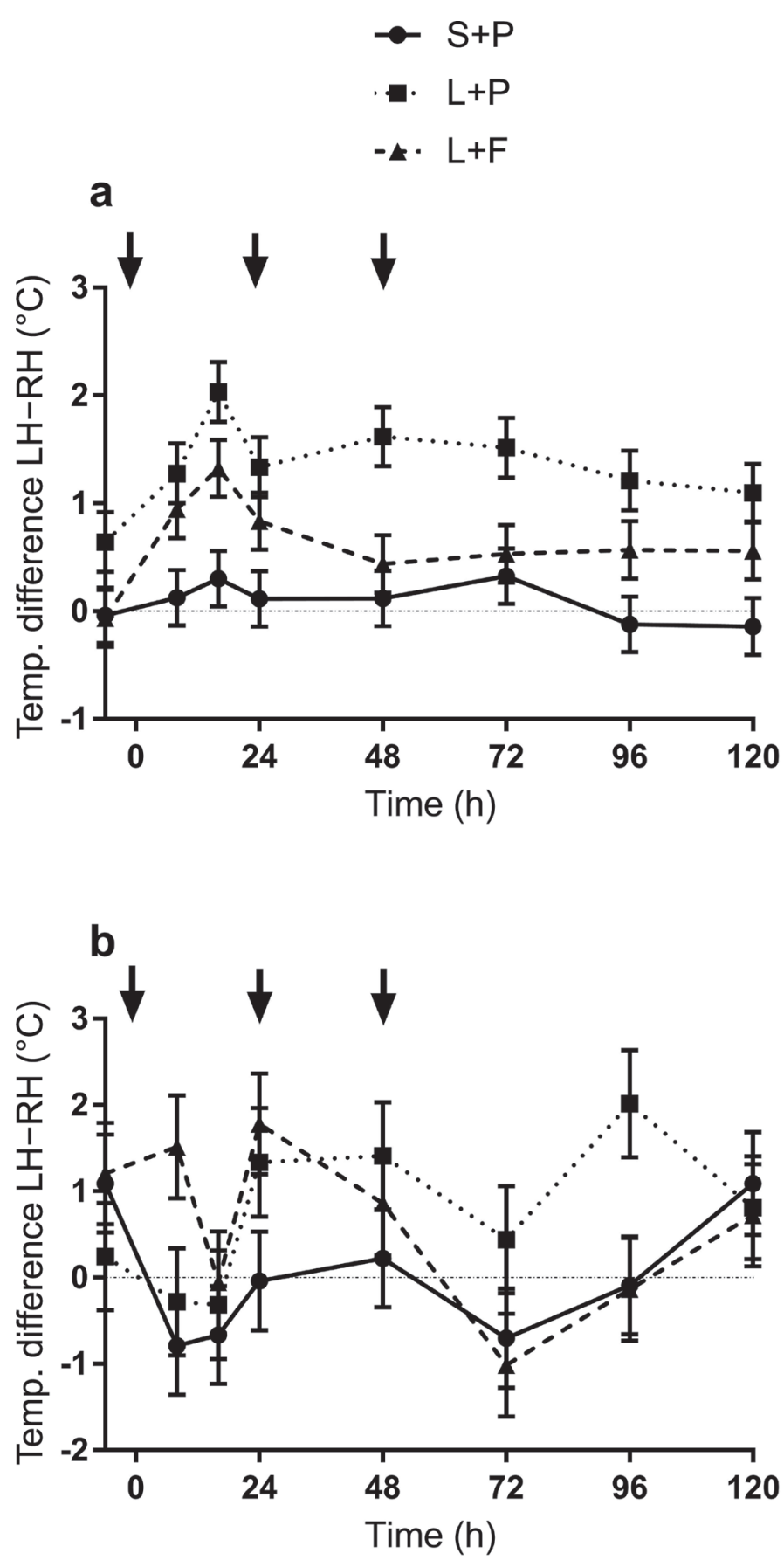

Figure 3. Infrared thermography (IRT) difference between the maximum (a, top) and minimum (b, bottom) temperatures (Temp.) of the left hind (LH; lame) and right hind ( $\mathrm{RH}$; nonlame) foot of cows with induced lameness using amphotericin $\mathrm{B}$ and treated with transdermal flunixin ( $\mathrm{L}+\mathrm{F}, \mathrm{n}=10 ; \downarrow$ indicates dosing times) at $3.33 \mathrm{mg} /$ $\mathrm{kg}(1 \mathrm{~mL} / 15 \mathrm{~kg})$; with induced lameness treated with a topical placebo $(\mathrm{L}+\mathrm{P}, \mathrm{n}=10)$ at $1 \mathrm{~mL} / 15 \mathrm{~kg}$; or with sham lameness induction treated with a topical placebo $(\mathrm{S}+\mathrm{P} ; \mathrm{n}=10)$ at $1 \mathrm{~mL} / 15 \mathrm{~kg}$. Error bars indicate SEM. temperatures in the $\mathrm{L}+\mathrm{F}$ and $\mathrm{L}+\mathrm{P}$ groups, but not the $\mathrm{S}+\mathrm{P}$ group, are indicative of hyperesthesia and inflammation of the affected foot caused by amphotericin B injection into the joint. These changes provide additional support for the utility of the model in inducing lameness as well as further information on pain relative to lameness. At the time of final data collection, some cows in the induced-lameness groups were no longer visibly lame but still had elevated IRT temperatures and decreased MNT measures, suggesting that inflammation was still present in the joint.

Transdermal flunixin meglumine is the only drug with a pain control approval for cattle in the United States. However, this approval is for the control of pain associated with foot rot, and any use beyond that disease condition is considered extra-label drug use. Approval of Finadyne Transdermal (Merck Animal Health, Madison, NJ) was granted after the study described here was conducted. To gain approval by the FDA, the drug sponsor used a foot rot model to induce disease in calves. That model used the causative agent Fusobacterium necrophorum to cause lameness in the desired limb (FDA, 2017).

Because transdermal flunixin has a pain control label for foot rot in cattle, the present study is important because it evaluated pain caused by a different mechanism. Amphotericin B, when placed intra-articular, causes a local arthritis and synovitis (McIlwraith et al., 1979). Injection in the lateral distal interphalangeal joint was used because the majority of lameness occurs in the lateral hind digit (Murray et al., 1996). There are presently no models for induction of sole ulcers or white line disease, 2 common causes of lameness in dairy cattle (Shearer and van Amstel, 2017). The causative event leading to sole ulcers typically occurs week to months before a sole ulcer is clinically noted (Shearer and van Amstel, 2017). These changes cause disruption in growth and development of corium, leading to a lesion that causes inflammation to the corium. The inflammation of the corium is different from the arthritis/synovitis caused by amphotericin B. Cows with naturally occurring lameness may have either lesions in other feet or more than one lameness-causing etiology in the same foot (e.g., sole ulcer and digital dermatitis occurring concurrently). The use of amphotericin B allows for induction of lameness without confounding of lesions in other limbs or multiple lesions in the same foot. A potential limitation of the model is the acute lameness it creates, whereas other lameness lesions are typically more chronic in nature.

Multiple doses of transdermal flunixin were evaluated in the present study and were warranted, as cows in the 2 lame groups had signs of lameness and decreased MNT beyond $24 \mathrm{~h}$. The pharmacokinetics of transder- 
Table 3. Least squares means $( \pm \mathrm{SE})$ of outcome measures from pressure mat gait analysis in cows with induced lameness

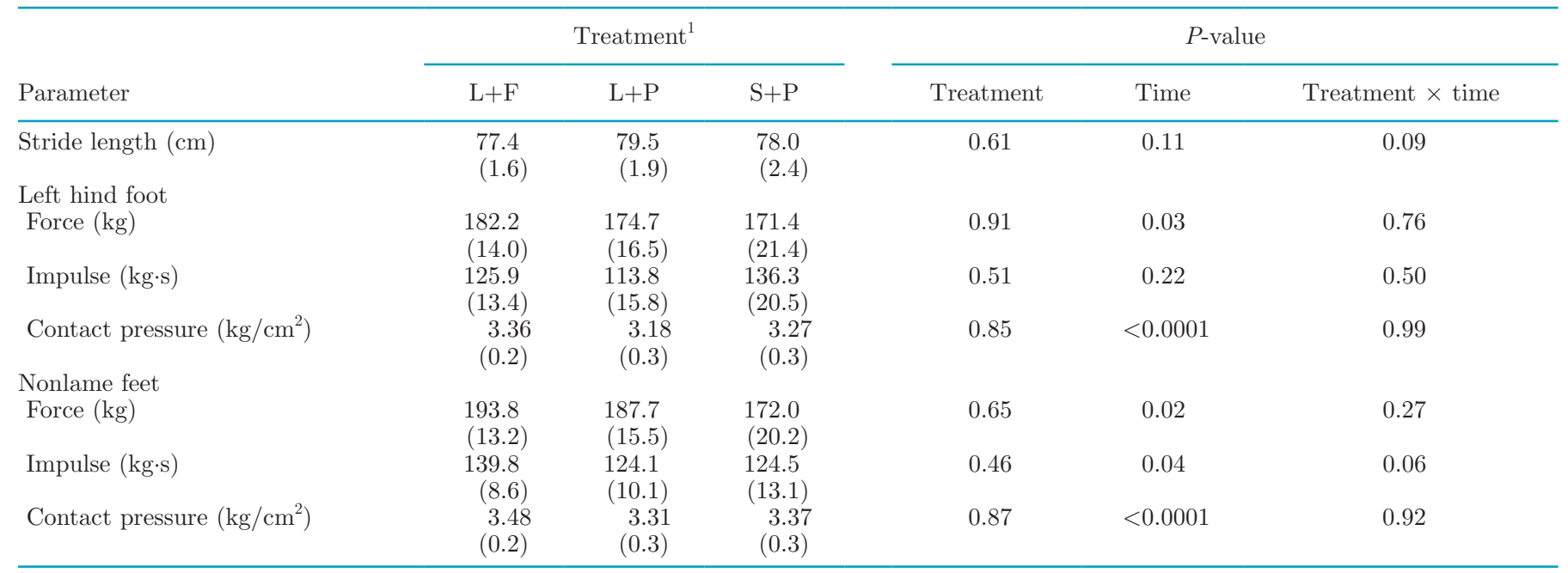

${ }^{1}$ Lameness was induced in the left hind lateral distal interphalangeal joint using amphotericin $\mathrm{B}$ and treated with transdermal flunixin $(\mathrm{L}+\mathrm{F}$; $\mathrm{n}=10)$ at $3.33 \mathrm{mg} / \mathrm{kg}(1 \mathrm{~mL} / 15 \mathrm{~kg})$ or a topical placebo $(\mathrm{L}+\mathrm{P} ; \mathrm{n}=10)$ at $1 \mathrm{~mL} / 15 \mathrm{~kg}$; or sham lameness was induced $(\mathrm{S}+\mathrm{P} ; \mathrm{n}=10)$ and treated with a topical placebo at $1 \mathrm{~mL} / 15 \mathrm{~kg}$.

mal flunixin in adult Holsteins administered 3 doses at 24-h intervals has been described by Kleinhenz et al. (2018). In their study, the plasma elimination half-life was $5.2 \mathrm{~h}$, the time to maximum concentration was $2.8 \mathrm{~h}$, and the accumulation factor was 1.1, indicating that little to no accumulation occurred after multiple administrations (Kleinhenz et al., 2018). These pharmacokinetic parameters support the dosing regimen of $3.33 \mathrm{mg} / \mathrm{kg}$ at 24 -h intervals, with low likelihood of adverse reactions and toxic effects. Because the flunixin formulation was not approved for use in the United States at the time of our study, cattle in the $\mathrm{L}+\mathrm{F}$ group did not enter the food chain. Currently transdermal flunixin is not approved for lactating dairy cattle in the United States. Therefore, use in this production class of animals constitutes an extra-label drug use and requires a valid veterinarian-client-patient relationship. Additionally, milk from all cattle was diverted from the food chain to prevent potential amphotericin B residues.

Lameness was evaluated using 2 methods. The VLS has been previously used in lameness research and clinical applications. The VLS describes the grade of lameness on a scale from 0 to 4 , with data compared using categorical methods. The second method for evaluating lameness was a VAS. The VAS was set on a $10-\mathrm{cm}$ line, with $0 \mathrm{~cm}$ indicating no lameness and $10 \mathrm{~cm}$ as severe lameness. A VAS of $1.5 \mathrm{~cm}$ would be equivalent to a VLS of 1 to 2 . The VAS measures allow for increased differentiation of lameness severity within VLS classifications. Thus 2 cows with similar VLS measures could receive different VAS measures. Additionally,
VAS measures can be treated as continuous data and incorporated as such in the statistical model.

Lameness scores, evaluated using either method, were low in this study compared with previous reports, implying that the cows were only mildly lame. Peak VAS scores were seen at the time of initial treatment. However, cows in the $\mathrm{L}+\mathrm{F}$ group had VAS scores that were double those of the $\mathrm{L}+\mathrm{P}$ group, but these differences were not evident at $8 \mathrm{~h}$ post-treatment. The use of flunixin may have contributed to this outcome, especially because this time point is after the time of maximum drug concentration reported in adult cows (Kleinhenz et al., 2018). The degree of lameness, as judged by mean VAS scores, persisted longer in the $\mathrm{L}+\mathrm{P}$ group throughout the study. However, it should be noted that there were cows in the $\mathrm{L}+\mathrm{P}$ group with no visual lameness at the time of treatment. To account for differences in VLS and VAS measures at the time of initial drug administration, VLS was included as a covariate in the statistical model. The inclusion of VLS in the statistical model did not appear to change the interpretation of our model.

Measurement of MNT has been described as an effective, noninvasive test for hyperalgesia in dairy cows (Tadich et al., 2013) and sows (Tapper et al., 2013; Pairis-Garcia et al., 2014). In this study, MNT showed increased sensitivity following lameness induction, when the left (affected) foot was compared with the right foot (control) as an intra-animal control and when raw MNT values between groups were compared. The right hind served as a control, but we discovered evidence of a time effect, with the mean MNT decreasing at 8 and 
$16 \mathrm{~h}$ after initial treatment in all groups. This is likely due to the amount of standing the cows did for sampling before the 16-h time point. Additionally, changes in MNT reflect the changes in visual lameness scores. The data suggest that a second dose of flunixin may be warranted, as cows in the $\mathrm{L}+\mathrm{F}$ group had similar MNT levels to the $\mathrm{L}+\mathrm{P}$ group at $24 \mathrm{~h}$ but not $48 \mathrm{~h}$ (Figure 4).

The MNT data were further supported by the differences in maximum temperatures of the left and right feet taken by IRT. The differences in the $\mathrm{L}+\mathrm{F}$ and $\mathrm{L}+\mathrm{P}$ maximum temperatures increased from baseline and peaked at $16 \mathrm{~h}$. There were differences between the 2 induced-lameness groups at 48, 72, 96, and 120 h. These differences were observed after the second and third dose of flunixin were administered at $24 \mathrm{~h}$ and $48 \mathrm{~h}$ respectively. At $48 \mathrm{~h}$, the $\mathrm{L}+\mathrm{F}$ mean temperature difference approached that of the $\mathrm{S}+\mathrm{P}$ group, indicating that flunixin had decreased the amount of inflammation in the foot. The elevation of maximum temperature differences, observed via IRT, are indicative of inflammation in the area (Rekant et al., 2016). The differences between the left hind temperature and right hind temperature were used to account for environmental factors such as ambient temperature and humidity, which play a role in IRT measures (Church et al., 2014). Previous studies have shown IRT to be sensitive in the detection of lameness and inflammation, but specificity was poor (Stokes et al., 2012; Alsaaod et al., 2014). The temperature differences reported in the present study were consistent with those found in cows with lesions at routine hoof trimming (Alsaaod et al., 2014).

The blood biomarkers tested in this study provide marginal evidence to support the effectiveness of transdermal flunixin in this pain model. The cortisol concentrations for the $\mathrm{L}+\mathrm{F}$ cows were significantly lower than for the $\mathrm{L}+\mathrm{P}$ and $\mathrm{S}+\mathrm{P}$ groups, for all time points except the baseline samples and at 0.5 and $1 \mathrm{~h}$ after drug application. Cortisol is not a specific biomarker for pain but an indicator of stress (Anil et al., 2002). In other lameness-induction studies, cortisol did not statistically differ between treatment groups (Kotschwar et al., 2009; Schulz et al., 2011; Coetzee et al., 2014).

In the current study, all cows were handled in the same system and housed together in a single pen, thus decreasing study procedures as a source of differences in outcomes. Cows enrolled in the $\mathrm{S}+\mathrm{P}$ group had numerically higher baseline cortisol levels compared with $\mathrm{L}+\mathrm{F}$ and $\mathrm{L}+\mathrm{P}$ groups. Therefore, baseline cortisol values were examined as a covariate in the model due to the differences observed. Inclusion of baseline cortisol as a covariate in the statistical model did not change the coefficients or interpretation of outcomes and were not included in the final model.

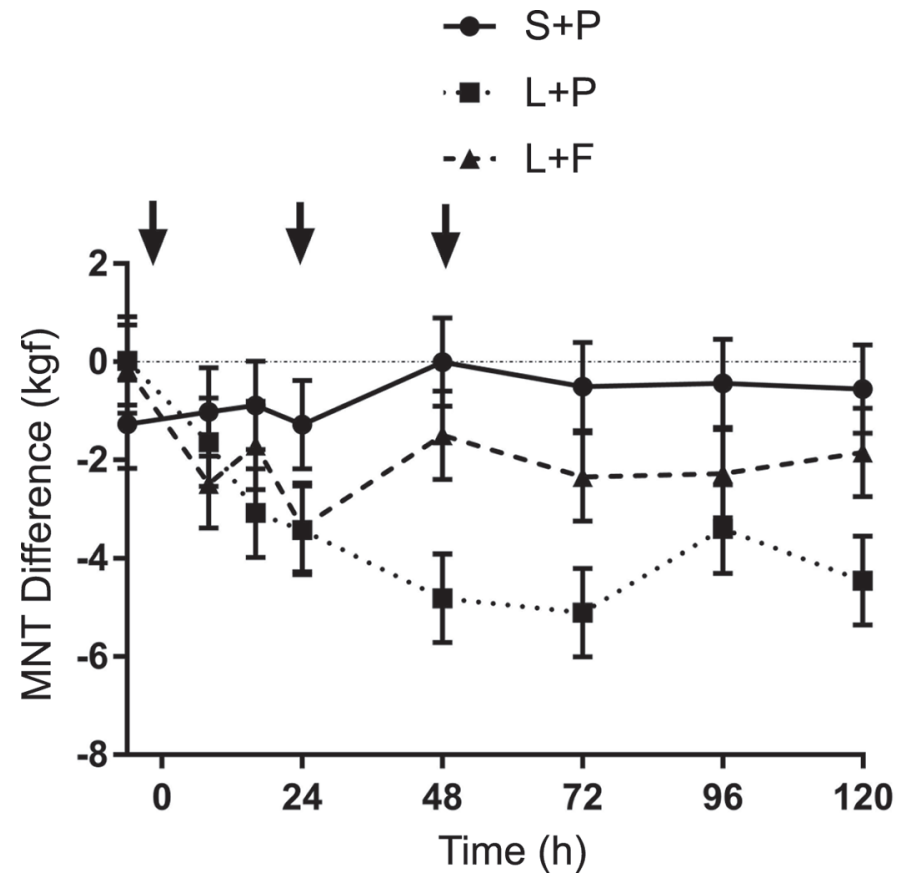

Figure 4. Mechanical nociception threshold (MNT; kilogramsforce) difference between the left hind (lame) and right hind (nonlame) foot of cows with induced lameness using amphotericin B and treated with transdermal flunixin ( $\mathrm{L}+\mathrm{F}, \mathrm{n}=10 ; \downarrow$ indicates dosing times) at $3.33 \mathrm{mg} / \mathrm{kg}(1 \mathrm{~mL} / 15 \mathrm{~kg})$; with induced lameness treated with a topical placebo $(\mathrm{L}+\mathrm{P}, \mathrm{n}=10)$ at $1 \mathrm{~mL} / 15 \mathrm{~kg}$; or with sham lameness induction treated with a topical placebo $(\mathrm{S}+\mathrm{P}, \mathrm{n}=10)$ at $1 \mathrm{~mL} / 15 \mathrm{~kg}$. Error bars indicate SEM.

Peak cortisol concentration for the $\mathrm{L}+\mathrm{F}$ group was observed at $0.5 \mathrm{~h}$ after initial drug treatment. This is in contrast to the peak cortisol concentration for the $\mathrm{L}+\mathrm{P}$ and $\mathrm{S}+\mathrm{P}$ groups, which occurred at $6 \mathrm{~h}$ after initial drug treatment. The observed increase at $6 \mathrm{~h}$ may be due to re-restraining the cows following a 2-h break from data collection. However, an increase in cortisol concentration among the $\mathrm{L}+\mathrm{F}$ group was not observed at this time point. Additionally, increases in cortisol concentrations were observed at $40 \mathrm{~h}$ and $64 \mathrm{~h}$ for all groups. These time points correlate to early morning collections, as the 24-, 48-, and 72-h collections occurred at $1200 \mathrm{~h}$.

One limitation to the collection and analysis of the cortisol data in the present study is that a cortisol sample was not collected at the time of initial treatment. Furthermore, the study location where cortisol samples were collected was different for the 0.5- to 6-h time points compared with baseline and samples collected after $8 \mathrm{~h}$ across all treatment groups. Specifically, cows were restrained in headlocks for the 0.5- to 6-h time points, due to farm-specific management practices and logistics. Therefore, elevations in cortisol concentrations during the 0.5 - to 6 -h time frame were likely 
reflective of stress associated with lame cows standing for prolonged periods. Conversely, starting at $8 \mathrm{~h}$, the cows had to walk to treatment chutes for collection of other outcome parameters such as IRT and MNT. Thus, elevations in the cortisol concentrations at the later time points were likely reflective of stress associated with lame cows being forced to walk. Methods to collect the blood sample (restraint via halter and venipuncture) were consistent regardless of sampling location but should still be considered when evaluating the cortisol concentrations over time.

There is little published data regarding substance $\mathrm{P}$ in either naturally occurring lameness or following induction in lameness models. In an oligofructose overload model inducing laminitis, the authors were able to show a difference in substance $\mathrm{P}$ levels between laminitis and nonlaminitis groups (Bustamante et al., 2015). Those researchers did not include an analgesic component in the study design. The range of treatment differences in the data presented in the present study, although inconclusive, indicate that further investigation into the correlation of lameness and neuropeptide concentrations, especially in naturally occurring lameness, is warranted. Substance P is a neuropeptide that has been shown to be associated with nociception in cattle (Coetzee et al., 2008). In horses, synovial concentrations of substance $\mathrm{P}$ were elevated in joints with osteoarthritis compared with non-diseased joints. Substance P levels have also been correlated with prostaglandin $\mathrm{E}_{2}$ concentrations in arthritic joints (Kirker-Head et al., 2000).

Gait analysis using a floor-based pressure mat system was used to gain approval for the use of transdermal flunixin for control of pain due to foot rot (FDA, 2017). Other studies using the amphotericin B induction model used a similar gait analysis method (Kotschwar et al., 2009; Schulz et al., 2011; Coetzee et al., 2014). Schulz et al. (2011) found increases in force, contact area, and impulse between calves treated with flunixin following lameness induction. Similarly, Coetzee et al. (2014) reported numerical increases in step impulse between calves treated with meloxicam and gabapentin following lameness induction. There were also numerical increases in total force and contact area for calves treated with meloxicam and gabapentin compared with placebo controls. Using the pressure mat technology in the present study, we found no evidence of treatment differences, despite differences in lameness at the time of initial treatment. In the previously published studies and freedom of information summary data, the cattle used were lighter weight than those used in the current study. Adjustments were made to the mat to allow for the increased weight of mature cows walking across it. These adjustments included placing a thicker rubber mat over the pressure sensors and decreasing the sensitivity of the system. The pressure mat system was calibrated daily using a known weight. The uneven distribution of lameness among the induced-lameness groups may have contributed to the lack of observed treatment differences. Furthermore, both lame groups had cows with VLS of 0, especially at the later time points. Visual lameness scores were included in the statistical model and found to be not a significant contributing factor. The time effects seen in the nonlame limbs were interrelated, because impulse and contact pressure have a function of force embedded in them.

In the study reported here, cows were enrolled and randomized to their respective treatment groups before lameness induction. In future studies, animals should be randomized to treatment group after lameness has developed, to reduce the variability in the severity of the lameness across treatment groups before drug administration. Additionally, a time point at which cows have pressure mat data collected after lameness induction but before treatment intervention would be prudent, to further characterize gait changes associated with lameness and treatment.

Flunixin, given by intravenous injection, has been evaluated in cattle lameness previously (Chapinal et al., 2010; Schulz et al., 2011; Wagner et al., 2017). Schulz et al. (2011) used amphotericin B to induce lameness in calves and found that flunixin was successful in providing analgesia. Flunixin-treated calves spent less time lying after lameness induction and had greater force and contact area walking across a gait-analysis system similar to the one used in the current study. The studies by Chapinal et al. (2010) and Wagner et al. (2017) followed dairy cows and used weight-shifting of the rear limbs as the main endpoint. Chapinal et al. (2010) investigated cows following hoof-trimming and found no evidence for treatment differences between flunixintreated cows and saline controls. However, the inclusion of nonlame cows may have diluted the differences seen between treatments. Wagner et al. (2017) followed only lame cows before these cows were trimmed by a hoof trimmer. The authors observed a difference in weight shifting between treatment groups, with the flunixintreated cows having decreased amounts of weight shifting. Changes in weight distribution were evident at 6 , 12, and $24 \mathrm{~h}$ post-treatment. The authors attributed this decrease in weight shifting to alleviation of pain by flunixin (Wagner et al., 2017). Based on the Schulz et al. (2017) and Wagner et al. (2017) studies, we can reasonably conclude that flunixin provides analgesia to cattle with lameness. This supports our findings of improved MNT and VAS measures in the $\mathrm{L}+\mathrm{F}$ cows following transdermal flunixin administration.

When all outcome variables were taken into account, there appears to be a benefit in providing transdermal 
flunixin to cows with induced lameness. Lameness scores improved in both the $\mathrm{L}+\mathrm{F}$ and $\mathrm{L}+\mathrm{P}$ groups based on lower VAS measures by $24 \mathrm{~h}$. However, we discovered no evidence of differences in MNT and IRT measures at $24 \mathrm{~h}$ in the lame groups. Observed differences in MNT and IRT measures became evident following the second administered dose at $24 \mathrm{~h}$ and measures taken before the third dose at $48 \mathrm{~h}$. The increased MNT scores in the $\mathrm{L}+\mathrm{F}$ but not the $\mathrm{L}+\mathrm{P}$ group provide evidence of improved tolerance to painful stimuli after the second treatment. The increases in MNT measures were also supported by decreased maximum temperatures taken by IRT and the associated inflammation of foot. Based on the MNT and IRT data, a second dose of flunixin was needed to provide additional analgesia and antiinflammatory effects in cows with induced lameness. The inclusion of the third dose provided little to no additional benefit based on the observed VLS, MNT, and IRT measurements. This is based on how the measures either minimally improved between the 48- to 72-h time points or did not improve at all.

\section{CONCLUSIONS}

Transdermal flunixin is an effective analgesic agent when treating induced mild lameness. Multiple doses of transdermal flunixin may be required, as MNT and IRT differences were first noted after the administration of a second dose. Further investigation of transdermal flunixin and its analgesic effects in severe lameness cases and naturally occurring lameness are warranted.

\section{ACKNOWLEDGMENTS}

This study was funded by the Pharmacology Analytical Support Team (PhAST) at the College of Veterinary Medicine, Iowa State University. The authors thank McKenzie Smith, Michael Burchard, Curtis Korthanke, Cassie Rice, Heather Tauke, and Aislinn Pomfret for their assistance with this study. This paper represents a portion of M. Kleinhenz's PhD dissertation for partial fulfilment in the graduate college at Kansas State University. The authors declare no conflicts of interests.

\section{REFERENCES}

Adams, A. E., J. E. Lombard, C. P. Fossler, I. N. Roman-Muniz, and C. A. Kopral. 2017. Associations between housing and management practices and the prevalence of lameness, hock lesions, and thin cows on US dairy operations. J. Dairy Sci. 100:2119-2136. https://doi.org/10.3168/jds.2016-11517.

Alsaaod, M., C. Syring, J. Dietrich, M. G. Doherr, T. Gujan, and A. Steiner. 2014. A field trial of infrared thermography as a noninvasive diagnostic tool for early detection of digital dermatitis in dairy cows. Vet. J. 199:281-285. https://doi.org/10.1016/j.tvjl .2013.11.028.
Anil, S. S., L. Anil, and J. Deen. 2002. Challenges of pain assessment in domestic animals. J. Am. Vet. Med. Assoc. 220:313-319. https: //doi.org/10.2460/javma.2002.220.313.

Bustamante, H. A., A. R. Rodriguez, D. E. Herzberg, and M. P. Werner. 2015. Stress and pain response after oligofructose inducedlameness in dairy heifers. J. Vet. Sci. 16:405-411. https://doi.org/ 10.4142/jvs.2015.16.4.405.

Chapinal, N., A. M. de Passille, J. Rushen, and S. A. Wagner. 2010. Effect of analgesia during hoof trimming on gait, weight distribution, and activity of dairy cattle. J. Dairy Sci. 93:3039-3046. https: //doi.org/10.3168/jds.2009-2987.

Church, J. S., P. R. Hegadoren, M. J. Paetkau, C. C. Miller, G. RegevShoshani, A. L. Schaefer, and K. S. Schwartzkopf-Genswein. 2014. Influence of environmental factors on infrared eye temperature measurements in cattle. Res. Vet. Sci. 96:220-226. https://doi.org/ 10.1016/j.rvsc.2013.11.006.

Coetzee, J. F., B. V. Lubbers, S. E. Toerber, R. Gehring, D. U. Thomson, B. J. White, and M. D. Apley. 2008. Plasma concentrations of substance $\mathrm{P}$ and cortisol in beef calves after castration or simulated castration. Am. J. Vet. Res. 69:751-762. https://doi.org/10 .2460 /ajvr.69.6.751

Coetzee, J. F., R. A. Mosher, D. E. Anderson, B. Robert, L. E. Kohake, R. Gehring, B. J. White, B. KuKanich, and C. Wang. 2014. Impact of oral meloxicam administered alone or in combination with gabapentin on experimentally induced lameness in beef calves. J. Anim. Sci. 92:816-829. https://doi.org/10.2527/jas.2013-6999.

Coetzee, J. F., J. K. Shearer, M. L. Stock, M. D. Kleinhenz, and S. R. van Amstel. 2017. An update on the assessment and management of pain associated with lameness in cattle. Vet. Clin. North Am. Food Anim. Pract. 33:389-411. https://doi.org/10.1016/j .cvfa.2017.02.009.

Fajt, V. R., S. A. Wagner, and B. Norby. 2011. Analgesic drug administration and attitudes about analgesia in cattle among bovine practitioners in the United States. J. Am. Vet. Med. Assoc. 238:755-767. https://doi.org/10.2460/javma.238.6.755.

FASS. 2010. Dairy cattle. Pages $74-88$ in Guide for the Care and Use of Agricultural Animals in Teaching and Research. 3rd ed. FASS, Champaign, IL

FDA (US Food and Drug Administration). 2017. Freedom of information summary original new animal drug application Banamine Transdermal. US FDA CVM. Accessed Sep. 30, 2017. https:// animaldrugsatfda.fda.gov/adafda/app/search/public/document/ downloadFoi/1944.

Flower, F. C., and D. M. Weary. 2006. Effect of hoof pathologies on subjective assessments of dairy cow gait. J. Dairy Sci. 89:139-146. https://doi.org/10.3168/jds.S0022-0302(06)72077-X.

Kirker-Head, C. A., V. K. Chandna, R. K. Agarwal, E. A. Morris, A. Tidwell, M. W. O'Callaghan, W. Rand, and M. S. Kumar. 2000. Concentrations of substance $\mathrm{P}$ and prostaglandin $\mathrm{E} 2$ in synovial fluid of normal and abnormal joints of horses. Am. J. Vet. Res. 61:714-718.

Kleinhenz, M. D., P. J. Gorden, J. S. Smith, J. A. Schleining, K. E. Kleinhenz, L. L. Wulf, P. K. Sidhu, D. Rea, and J. F. Coetzee. 2018. Pharmacokinetics of multiple doses of transdermal flunixin meglumine in adult Holstein dairy cows. J. Vet. Pharmacol. Ther. 41:490-493. https://doi.org/10.1111/jvp.12490.

Kotschwar, J. L., J. F. Coetzee, D. E. Anderson, R. Gehring, B. KuKanich, and M. D. Apley. 2009. Analgesic efficacy of sodium salicylate in an amphotericin B-induced bovine synovitis-arthritis model. J. Dairy Sci. 92:3731-3743. https://doi.org/10.3168/jds .2009-2058.

McIlwraith, C. W., J. F. Fessler, W. E. Blevins, E. H. Page, A. H. Rebar, D. C. Vansickle, and G. L. Coppoc. 1979. Experimentally induced arthritis of the equine carpus - clinical determinations. Am. J. Vet. Res. 40:11-20.

Murray, R. D., D. Y. Downham, M. J. Clarkson, W. B. Faull, J. W. Hughes, F. J. Manson, J. B. Merritt, W. B. Russell, J. E. Sutherst, and W. R. Ward. 1996. Epidemiology of lameness in dairy cattle: Description and analysis of foot lesions. Vet. Rec. 138:586-591. 
NRC. 2001. Nutrient Requirements of Dairy Cattle. 7th rev. ed. The National Academies Press, Washington, DC. https://doi.org/10 $.17226 / 9825$.

Pairis-Garcia, M. D., A. K. Johnson, K. J. Stalder, L. A. Karriker, J. F. Coetzee, and S. T. Millman. 2014. Measuring the efficacy of flunixin meglumine and meloxicam for lame sows using nociceptive threshold tests. Anim. Welf. 23:219-229. https://doi.org/10.7120/ 09627286.23.2.219.

Rekant, S. I., M. A. Lyons, J. M. Pacheco, J. Arzt, and L. L. Rodriguez. 2016. Veterinary applications of infrared thermography. Am. J. Vet. Res. 77:98-107. https://doi.org/10.2460/ajvr.77.1.98.

Schulz, K. L., D. E. Anderson, J. F. Coetzee, B. J. White, and M. D. Miesner. 2011. Effect of flunixin meglumine on the amelioration of lameness in dairy steers with amphotericin B-induced transient synovitis-arthritis. Am. J. Vet. Res. 72:1431-1438. https://doi .org/10.2460/ajvr.72.11.1431.

Shearer, J. K., and S. R. van Amstel. 2017. Pathogenesis and treatment of sole ulcers and white line disease. Vet. Clin. North Am. Food Anim. Pract. 33:283-300. https://doi.org/10.1016/j.cvfa 2017.03.001.

Sprecher, D. J., D. E. Hostetler, and J. B. Kaneene. 1997. A lameness scoring system that uses posture and gait to predict dairy cattle reproductive performance. Theriogenology 47:1179-1187.

Stokes, J. E., K. A. Leach, D. C. Main, and H. R. Whay. 2012. An investigation into the use of infrared thermography (IRT) as a rapid diagnostic tool for foot lesions in dairy cattle. Vet. J. 193:674-678. https://doi.org/10.1016/j.tvjl.2012.06.052.

Tadich, N., C. Tejeda, S. Bastias, C. Rosenfeld, and L. E. Green. 2013. Nociceptive threshold, blood constituents and physiological values in 213 cows with locomotion scores ranging from normal to severely lame. Vet. J. 197:401-405. https://doi.org/10.1016/j.tvjl .2013.01.029.

Tapper, K. R., A. K. Johnson, L. A. Karriker, K. J. Stalder, R. L. Parsons, C. Wang, and S. T. Millman. 2013. Pressure algometry and thermal sensitivity for assessing pain sensitivity and effects of flunixin meglumine and sodium salicylate in a transient lameness model in sows. Livest. Sci. 157:245-253. https://doi.org/10.1016/ j.livsci.2013.07.017.

Van Engen, N. K., M. L. Stock, T. Engelken, R. C. Vann, L. W. Wulf, L. A. Karriker, W. D. Busby, J. Lakritz, A. J. Carpenter, B. J. Bradford, W. H. Hsu, C. Wang, and J. F. Coetzee. 2014. Impact of oral meloxicam on circulating physiological biomarkers of stress and inflammation in beef steers after long-distance transportation. J. Anim. Sci. 92:498-510. https://doi.org/10.2527/jas.2013-6857.

von Keyserlingk, M. A., A. Barrientos, K. Ito, E. Galo, and D. M. Weary. 2012. Benchmarking cow comfort on North American freestall dairies: Lameness, leg injuries, lying time, facility design, and management for high-producing Holstein dairy cows. J. Dairy Sci. 95:7399-7408. https://doi.org/10.3168/jds.2012-5807.

Wagner, S. A., J. M. Young, J. K. Tena, and B. H. Manning. 2017. Behavioral evaluation of the analgesic effect of flunixin meglumine in lame dairy cows. J. Dairy Sci. 100:6562-6566. https://doi.org/ 10.3168/jds.2016-12331.

Whay, H. R., and J. K. Shearer. 2017. The impact of lameness on welfare of the dairy cow. Vet. Clin. North Am. Food Anim. Pract. 33:153-164. https://doi.org/10.1016/j.cvfa.2017.02.008. 